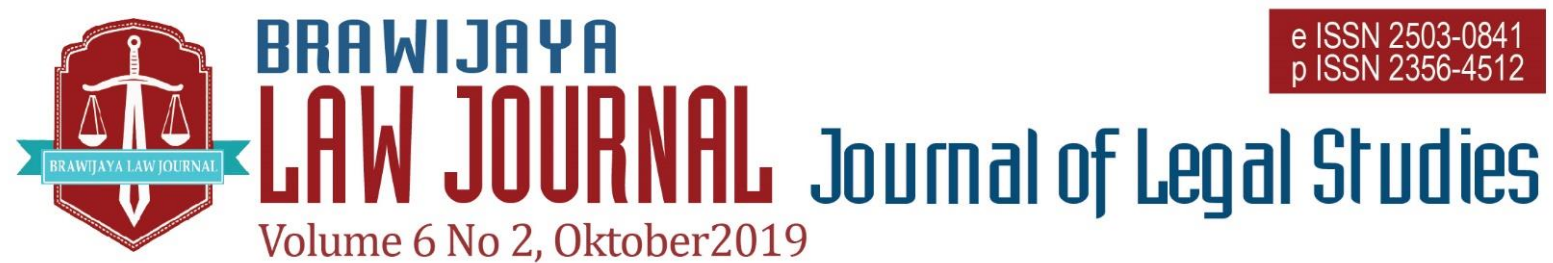

Nationally Accredited No. 30/E/KPT/2018 Dated 24th October 2018

This work is licensed under a Creative Commons Attribution-NonCommercial 4.0 International License

\title{
Urgency of the Contempt of Court Criminalization Policy to Overcome Harassment Against the Status and Dignity of Courts
}

\author{
Hari Sutra Disemadi ${ }^{\mathrm{a}}$, Kholis Roisah ${ }^{\mathrm{b}}$ \\ ${ }^{a, b}$ Faculty of Law, Diponegoro University, Semarang, Indonesia \\ Email: haridisemadi@gmail.com
}

Submitted : 2019-08-02 | Accepted : 2019-09-06

\begin{abstract}
In Indonesia, many cases that occur related to contempt of court and law enforcement have occurred. The issue of Contempt of Court in Indonesia is a problem that is both interesting and complicated in its conception and regulation. Until now, in Indonesia, no provisions specifically regulating the Contempt of Court institutions. This completed study uses a normative juridical research method that prioritizes secondary data. This research addressing the legislation governing the Contempt of Court specifically until now still does not yet exist. However, the general arrangement has happened in the Criminal Code. Contempt of Court can occur both in the courtroom and outside the trial both in criminal, civil and industrial relations cases. Increasingly expanding various actions, which can be categorizing as contempt of court in Indonesia, it is necessary to arrange Contempt of Court in the form of separate rules
\end{abstract}

Keywords: urgency; criminalization policy; contempt of court.

\section{INTRODUCTION}

Current progress has led to many changes. The social aspects that were formerly considered taboo were due to the modernization of the taboo thing that has passed. Even something that has previously considered an area that is impossible to change has easily been changed by it, for example, religious traditions, community social relations and law. ${ }^{1}$

\footnotetext{
Ida K. Jeumpa, 'Contempt Of Court: A Comparison Among Vary Legal Systems' (2014) 62 Kanun Jurnal Ilmu Hukum 147, 149.
}

If we look at the world of justice and law enforcement in Indonesia, almost every day we are treated to various stories or news about unsatisfactory judicial practices. News about the judicial mafia, bribery at every stage of the court and the congregation atmosphere was like a place without rules, even though justice is a place to seek justice based on the applicable legal rules. ${ }^{2}$

It is not new if we see the visitors shouting, throwing eggs, clapping their hands, 
wearing masks and throwing chairs towards the panel of judges. ${ }^{3}$ The case that most tarnished the dignity of the judiciary in Indonesia was the murder that took place in the courtroom of the Sidoarjo Religious Court (Pengadilan Agama), East Java, until a judge being murder.

The lack of public trust in the judiciary is the root of the problem of the emergence acts of abuse against contempt of court. This lack of public trust is very influential on the integrity and authority of the judiciary as the last bastion to get justice. ${ }^{4}$

The issue of Contempt of Court in Indonesia is a problem that is both interesting and complicated in its conception and regulation. The terminology and understanding of the Contempt of Court in Indonesia is first to contain in the Supreme Court Law, which is the main implication, whether it is a person who imposes a person or more in a court case or not outside the court whose actions are actively or passively disturbing and polluting the criminal justice system that runs as it should, deterring and disturbing court officials who are authorized to carry out their duties, demeaning the dignity of the judiciary in public because it is like a court hearing is a sacred matter and the judge is an extension of God's hand because it expects that a justice which includes all parties in agreement. ${ }^{5}$

Indonesia is a legal state (Rechtsstaat) as confirmed by the provisions of Article 1 paragraph (3) of the 1945 Constitution. The nature of the state law upholds a legal system

3 Ida K. Jeumpa, above n 1., 152.

4 Binsar Gultom, Pandangan Seoarang Hakim Penegak Hukum Di Indonesia, (Medan: Pustaka Bangsa Press, 2006), p. 101.

5 Anita Afriana, and At Al, 'Contempt Of Court: Penegakan Hukum Dan Model Pengaturan Di Indonesia' (2018) 7(3) Jurnal Hukum Dan Peradilan 441, 450.

6 Aditya W. Mulyadi, above n 2., 337. that guarantees legal certainty (Rechts zekerheids) and protection of human rights. ${ }^{6}$ A country based on law must guarantee the equality of each individual, including the independence of individuals to use their human rights. In this context, in addition to executive and legislative powers, there is judicial power in the manifestation of judicial power. ${ }^{7}$

In judicial power, there is a fundamental principle in the form of independence of the judiciary. The principle implies that the course of the judicial process must be a guarantee in a way to avoid all forms of influence, pressure, threats that come from any party that has the potential to reduce the nobility of the principle. The principle of independence of the judiciary said is universal and is applied in various countries. $^{8}$

Based on the above principles, the judicial process must be carried out openly, objectively, impartially following legal provisions and a sense of justice. So important is the position and function of the principle so that it gets special arrangements in the 1945 Constitution of the Indonesian Republic of Indonesia and then translated into various laws which specifically contain the main points of judicial power. Anyone, without exception, is obliged to respect the dignity and dignity of the court and all its apparatus. ${ }^{9}$

However, the implementation of judicial power in constitutional practice is relatively vulnerable which can be intervened

7 Lilik Mulyadi, 'Urgency and Prospects Settings (Ius Constituendum) on Contempt of Court Act to Uphold The Dignity and Justice Authority' (2015) 4(2) Jurnal Hukum dan Peradilan 275, 278.

8 Budi Suhariyanto, 'The Urgency of the Criminalization of Contempt of Court for the Effectiveness of Decision at Judicial State Administrative Court' (2019) 16(1) Jurnal Konstitusi 192, 198.

9 Binsar Gultom, above n 4, 105 
neither through legislative legal policies nor horizontal institutions, power in society (mass organizations, mass media, political parties) through the formation of public opinion at the time the judiciary is ongoing. The influence of parties that have political power interests, anarchic, decisive and compelling violence or mass mobilization has coloured the judicial process so that it disrupts the administration of the judicial process. $^{10}$

Based on the background of the above problems, it is necessary to attempt a criminalization policy by making a legal product and the concept of law enforcement against a case of abuse against contempt of court. Although not only legal products in the form of laws that can use as a solution to this problem, where bureaucratic reform can also be used as a step to increase public trust.

Previous research related to contempt of court was by Budi Suhariyanto in 2019, with the research title "The Urgency of the Criminalization of the Court of Effectiveness at Judicial State Administrative Court" published in the Journal Konstitusi of Volume 16 Number 1, The focus of this research is on the policy of criminalizing contempt of court against State Administration officials (TUN) who do not fulfill the TUN Court's decision, and by Ruby Hardiarti Johny in 2009, with the research title "Contempt Of Court (Kajian Tentang Ide Dasar Dan Implementasinya Dalam Hukum Pidana)" published in Jurnal Dinamika Hukum. Volumen 9 Number 2, the result of the research shows that the basic idea of the contempt of court-managed in the criminal code is closely related with and afford to promote the high authority and privilege. Contempt of Court in Indonesia is implemented in the articles which spread out of the Criminal Code especially offences related with "rechtspleging" and draft of law of criminal code which has been directed on its chapter itself namely Chapter VI about crime act on holding the judicature from the article 325 up to 335 of draft of law of the Criminal Code. The conducts which could classify as the contempt of court is nowadays essential in Indonesia to keep the authority and privilege of justice institution to take action against the actors of contempt of court to apply the articles of Criminal Code.

Based on previous research, there are differences in the focus of research that will be carried out by the authors with existing research. Although they both took the theme of contempt of court, the focus of this study is on: 1). Existence of contempt of court arrangements in Indonesia; and 2). The urgency of contempt of court arrangements by Indonesian judiciary.

\section{LEGAL MATERIALS AND METHODS}

The type of legal research used is legal research which is included in the normative legal research typology where this study focuses on positive legal norms in the form of legislation. Analytical descriptive is the nature of the research specifications used by the author because the specifications of this study describe and describe the problem of the object that is studied. The data that has obtained is then collected and then arranged to be analyzed and explained to get the conclusions of the research conducted.

Secondary data have used in writing this article. Secondary data is indirect data access from the source of the object of research. This data is in the form of legal material has juridical binding power (primary legal materials), legal materials that provides

10 Budi Suhariyanto, above n 8., 200.

226 | Disemadi, Roisah - Urgency of the Contempt of Court Criminalization Policy... 
further explanation of primary legal materials such as books, articles and internet related to the topic of this research (secondary legal materials) and legal material that gives explanation of the two legal materials above (tertiary legal materials), because this legal material is able to clarify terms and problems that might be encountered, for example, is a legal dictionary and other language dictionaries. The technique used in collecting secondary data is through library research or documentary study, which is a study that examines various documents both related to legislation and other available documents. The last thing is compiling data that have been obtained so that it becomes legal writing that can answer the problems that have formulated beforehand to help the author make a correct conclusion.

\section{RESULT AND DISCUSSION Existence of Legal Settings on Contempt Of Court In Indonesia}

The judicial power that contains freedom also means there is protection for judges and their institutions, from influences including the following: ${ }^{11}$ a). Institutions outside the judicial bodies both executive, legislative and others; b). Internal institutions within the ranks of the judicial authority itself; c). Influence of litigant parties; d). The influence of litigants both nationally and internationally; and e). Effects that are "trial by the press".

If the judge has high credibility and is being supported by a system that provides the freedom and independence of judges and their institutions, the public trust in the function of judges and court institutions will be better, people are happy that their case is

11 Hasbullah F. Sjawie, 'Sekelumat Catatan Mengenai Tindak Pidana "Contempt of Court" Di Indonesia' (1994) 4 Jurnal Hukum Dan Pembangunan 324, 329-330. processed because they believe they will get justice. ${ }^{12}$ The 1945 Constitution provides a legal basis for judicial authority through Article 24, then Act No. 14 the Year 1970 which was amended by Act No. 35 Year 1999 and now with the Act No. 4 the Year 2004. The independent judicial power is closely related to the Contempt of Court, which is an act that undermines the dignity, dignity and honour of the judicial body.

If it is seen that the existence of the Contempt of Court in Indonesia is contain in the general explanation point 4 of Act No. 14 the Year 1985 which was amended by Act No. 5 the Year 2004 concerning the Supreme Court which states that in order to better guarantee the creation of the best possible atmosphere for the administration of justice in order to uphold law and justice based on Pancasila, a law that regulates actions, behaviour, attitudes and or speeches is needed, can be degrading from the undermining of the dignity, dignity and honor of the judicial body known as the Contempt of Court. ${ }^{13}$

Actions that qualify for Contempt of Court according to the Civil Law System that aims to protect judicial bodies to maintain the effectiveness of the judicial system to function properly and fairly, and regulated in the codification of legislation of countries that embrace civil law. ${ }^{14}$ This regulation concerning Recht pleging is not a term of the crime of Contempt of Court but is known as a criminal act against the administration of justice, because of civil law, a criminal act against the administration of justice regulated in a Criminal Code (KUHP).

The basic idea of the Contempt of Court is to protect the dignity of the judiciary

12 Suriani, 'Pengaturan Hukum Pidana Terhadap Contempt Of Court' (2017) 2(3) Jurnal Pionir 1, 4.

13 Aditya W. Mulyadi, above n 2., 332.

14 Ida K. Jeumpa, above n, 1,169. 
in order to remain respectful and dignified as an independent, independent institution regardless of the influence of other parties (executive, legislative, internal institutions of the judiciary) or those who want to impose honour and authority judicial institutions, and this can concluded from the provisions of Article 24 of the 1945 Constitution.

In Indonesia, the Contempt of Court arrangement in positive law briefly regulated in the provisions of the material law (KUHP), formal law (KUHAP), as well as arrangements outside the Criminal Code and KUHAP. In the Criminal Code and the Criminal Procedure Code, it is arranged briefly about the Contempt of Court which essentially is anyone who intentionally interferes with, does not show respect and obstructs the performance of the competent officials both in the trial and outside the trial in the law with criminal penalties. ${ }^{15}$

Strictly speaking, it can be said that in fact until now, Indonesia still does not have its legal instruments that are sufficient to regulate and protect the dignity of the judiciary from various actions of various parties. The indication is that relatively few have tried for conducting Contempt of Court. ${ }^{16}$. The logical consequence is an urgent, urgent and urgent need for critical and academic studies and research to be carried out comprehensively towards the birth of the Law on Criminal Procedure for the Implementation of Courts to maintain nobility and uphold the dignity of the judiciary. ${ }^{17}$

15 Achmad Ali, Menguak Teori Hukum (Legal Theory) dan Teori Peradilan (Judicialprudence), (Jakarta: Kencana, 2012), p. 98.

16 Ruby H. Johny, 'Contempt Of Court (Kajian Tentang Ide Dasar Dan Implementasinya Dalam Hukum Pidana)' (2009) 9(2) Jurnal Dinamika Hukum 135, 140.
The Urgency of Contempt Of Court Settings According To Indonesian Justice

Court abuse, whether direct or indirect, is very possible, for example, on May 27, 2001, judges at the Medan District Court were verbally abused, pursued and spat on by the litigants. Even in Sumenep, there was once a judge who was chased by the masses until he fell into the river and was beaten only because the judge's decision was deemed not by local custom values. Recently, a public lawyer at the Jakarta Legal Aid Institute (LBH) was also reported by North Jakarta District Court judges to Peradi, among others, for being considered a Contempt of Court. ${ }^{18}$

Since Indonesian independence, there was the political will to regulate further the insult and threatening of instruments in court. However, this, in the end, is only limited to discourse. It is necessary to have separate arrangements regarding the Contempt of Court which are not only as currently only in the Criminal Code, as proposed by the Indonesian Judge Association (IKAHI) submitted to the legislature about the regulation of legal protection for judges. However, the proposal has not received a response from the legislature, that is possible because if the judiciary has given the protection it will have very strong immunity and it is feared that it can cause problems. Likewise, the opinion of Saryana is that a Contempt of court Bill has required outside the Criminal Code articles, so for more details, Contempt of court must be made special rules with a clear understanding of the Contempt of court. ${ }^{19}$

17 Ruby H. Johny, above n16., 140

18 Budi Suhariyanto, 'Contempt Of Court through The Perspective Of Progressive Law' (2016) 9(2) Jurnal Yudisial 151, 168.

19 Achmad Ali., above n,15., 122 
The lack of a clarify Contempt of Court arrangement, in practice, has led to injustice and legal uncertainty. Legal certainty requires the creation of general rules or generally accepted rules. ${ }^{20}$ The goal, to create a safe and peaceful atmosphere in the community, then these regulations must be enforced and implemented firmly. Thus, the rules of law must be known with certainty. It can be said that in essence legal certainty is a condition where human behaviour, both individuals, groups, and organizations, is bound and within the corridor that has been outlined by the rule of law. ${ }^{21}$. Three pillars in realizing legal certainty can be divide into legal certainty from the elements of the legislation, institutions and legal institutions, that manifested in the decisions of the institution. The creation of legal certainty can be realized on the condition that there are clear and non-interpretive laws or regulations. $^{22}$

The need to be clear rules as one of the pillars of effective and efficient law enforcement to achieve legal certainty, and criminalization of actions that harass the dignity of judges and courts is still needed. Making criminalization of actions to uphold the authority of the court is important, and this can be done only through clear rules and procedures. $^{23}$

The Contempt of Court rules that have so far been valid is only implicitly regulated in the Criminal Code. Considering that the Contempt of Court's actions has expanded to threaten the authority of the court, and it is necessary to have special rules as well as legal requirements. This is where the role of law is needed in development to ensure that change occurs in an orderly manner. ${ }^{24}$ Regularity in change can be assisted by legislation or court decisions so that it can be carried out in an orderly manner because both change and order are the goals of the people who are developing. Thus the law becomes a tool that cannot be ignored in the development process and can be said as law as a means of renewing society.

Legal development covers all aspects of people's lives, which are not only limited to legal norms and norms but also institutions and processes. Therefore, one aspect of the development of national law is related to material law and formal law. In the context of legal development, the results in this study are required for legal reform by the needs of the community. As an effort to uphold the law, it is time for Indonesia to have a regulation on the Contempt of Court, considering this is by the needs not only for judges but also for the community. ${ }^{25}$

Considering the increasing extent of actions that can be categorized as Contempt of Court, all actions and actions that in principle disrupt safety, psychological and physical calm, it is necessary to have a separate Contempt of Court arrangement, because it is a special crime, in the sense that the word has not integrated in the Criminal Code. The main principle of the Indonesian state which is the basis of the civil law system is that the law obtains binding power because it is embodied in regulations in the form of shrimp law and systematically arranged in certain codifications or compilations. ${ }^{26}$ This basic principle relates to the main value is the

\footnotetext{
20 Wildan Syafitri, “ Tinjauan Yuridis Penghinaan Terhadap Pengadilan Dalam Sistem Peradilan Pidana Indonesia' (2016) 3 (2), JOM 1, 12

21 Budi Suhariyanto, above n,18., 170.

22 Ruby H. Johny, above n16., 141.

23 Lilik Mulyadi., above, n, 7,90
}

24 Budi Suhariyanto, above n 18., 209.

25 Nur Kholis, 'Asas Non Diskriminasi Dalam Contempt of Court' (2018) 26(2), Jurnal Legality 210, 230.

26 Budi Suhariyanto, above n 18. 203. 
purpose of law in the legal system as legal certainty. Based on this matter, it becomes urgent to immediately make special rules regarding Contempt of Court. Contempt of Court forms that can be classified as types of harassment qualify as follows: ${ }^{27}$

$1)$. The behaviour is not polite in the trial (Misbehaving), which is all actions in the form of signals or statements of a threat to the court. The point is to behave in a disgraceful and inappropriate manner in the court. The types of violations included in misbehaving in court are one type of humiliation that occurs in the court. The meaning of misbehaving in court is that in every act or word that can hinder or obstruct the course of a normal and harmonious trial of the proceedings at the court. The type of misbehaving violation is an attack on the course of the trial. Misbehaving is one form of the Contempt of Court if the act or behaviour is such that it disrupts to order in a court session. As such, order and authority of the court need to return. The formulation contained in misbehaving in court is that every person who behaves in a disorderly manner, embarrassing or detrimental, disturbing, disrupts the normal course of a judicial process before the court, is wrong for committing a violation. In the Criminal Code the misbehaving act covered in Article 217 of the Criminal Code which criminalizes those who make noise and is unwilling to be issued can be intended in terms of misbehaving which is one element of the Contempt of Court. A misbehaving or disruption in a judicial process, by making noise, attack or physical disruption in its essence is not such a big problem, so that the judge only allows

27 Oemar Seno Adji, Peradilan Bebas Negara Hukum, (Surabaya: Erlangga, 1986), p. 221-222

28 Sutanto Nugroho, R.B. Sulatro and Budhi Wisaksono, 'Pengaturan Tindak Pidana Contempt or expels visitors as a preventive step in the occurrence of Contempt of Court; and

2). Make a court scandal (Scandalizing the Court). This form of Contempt is from actions or statements and attacks on impartiality from the court, which can be addressed to judges, prosecutors and witnesses carried out by the masses as visitors to the trial both in the trial and outside the trial which can cause a reversal effect, disrupt normal functions and smoothly regarding the Judicial process even though the Contempt has not directed against the Judge, prosecutor or witness but also the proceedings. Contempt Scandalizing the court type has a broad meaning about the situation and has other types of misbehaving or disruption in the court. This happens when it is a result of language which is a mild insult to the court or an attack on impartiality during the process.

The purpose of making the type of scandalizing the court is to protect the reputation of the court against impartiality, objectivity, or honesty of the court itself. ${ }^{28}$ Contempt of Court forms which can be categorized as disruptions to trials which are types of misbehaving in court and Scandalizing the Court, after a description or expression of analysis is held accompanied by a proposal for consideration of recommendations, it can be channelled in legislation in addition to the provisions in the Criminal Code as a violation of the course of the judicial process (Administration of Justice). ${ }^{29}$

Based on the Academic Script of the Contempt of Court Bill compiled by the Indonesian Judge Association (IKAHI), actions which include harassment of court

of Court Berdasarkan Sistem Hukum Pidana Indonesia' (2017) 6(2), Dipegoro Law Journal 1, 9.

29 Ruby H.Johny, above n,16,140.

230 | Disemadi, Roisah - Urgency of the Contempt of Court Criminalization Policy... 
dignity include 30 1). Despicable and inappropriate behaviour (misbehaving in court); 2). Not obeying court orders (disobeying in court order); 3). Attacking court integrity and impartiality (scandalizing the court); 4). Obstruct the running of the court (obstructing justice); 5). The acts of humiliation against the court are carried out by publication or notification (subjudice rule).

Based on the description above, it has been concluding that the Contempt of Court included two things: ${ }^{31} 1$ ). Actions are taken in the court session (contempt in the face of the court); 2). Publications considered to interfere with a fair judicial process in certain cases (publications in due course of justice in particular legal proceedings). In the Criminal Code Bill, contempt of court material has regulated in a special chapter which among other things regulates acts against the law in terms of not obeying court orders for the sake of judicial processes, insulting judges or attacking integrity, advocates who make agreements with opposing parties. It is worth noting that the act can harm the interests of the party being assisted, asking for compensation with the intention of influencing witnesses, interpreters, investigators, public prosecutors, or judges in the case concerned; use violence, threats of violence or intimidate investigators, investigators, public prosecutors, lawyers, and / or judges; does not come when called as a witness; damaging facilities, infrastructure and equipment for court hearings; direct attacks on witnesses or law enforcement officers and court officials; and make noise in court. ${ }^{32}$

30 Hasbullah F. Sjawie, above n,11, 329

31 Budi Suhariyanto, above n,18., 204.

32 Sareh Wiyono M, 'Urgensi Pembentukan UndangUndang Tentang Penghinaan Dalam Persidangan (Contempt of Court), Untuk Menegakkan Martabat
If you look at the substance of contempt of court in the Criminal Code Bill, it is clear that the regulation applies to the public outside the law enforcement apparatus. ${ }^{33}$ The Criminal Code Bill has not yet regulated what if law enforcers in the judiciary environment such as judges, investigators, and investigators carry out acts that demean the dignity, dignity or honour of the judiciary. Provisions that regulate legal protection for law enforcement officers in carrying out their duties are very adequate, but it is undeniable that law enforcers also have the potential to take actions that can undermine the dignity and dignity of the judiciary so that the contempt of court provisions apply also to enforcement officer's law. ${ }^{34}$

For civil society who reject the Bill on Contempt of Court proposed by the Indonesian Judge Association (IKAHI), consider the material in the Contempt Of Court Bill contains duplicate material in other laws, such as the Criminal Code, so It is has feared that overlapping arrangements will occur, the existence of the articles that have the potential to be used to criminalize some parties, and the potential for more limited public access to the courts. ${ }^{35}$ The articles in the Contempt Of Court Bill that contain controversy are the provisions of Article 20 and Article 25. Article 20 of the Contempt of Court Bill reads: "1) Any person who insults a judge or attacks the integrity or non-impartiality of a judge or an official who administers the court in connection with the implementation both oral and written judiciary, shall be punished with a maximum imprisonment of 8 (eight) years and/or a

\footnotetext{
dan Wibawa Peradilan' (2015) 4(2) Jurnal Hukum dan Peradilan 263, 266.

33 Suriani, above n 12, 4.

34 Budi Suhariyanto, above n, 18,210.

35 Sareh Wiyono M,above n,30, 267.
} 
maximum fine of Rp.1,000,000,000.00 (one billion rupiahs). 2) If this is done by writing broadcast through print or electronic media, it is threatened with imprisonment of a maximum of 10 (ten) years and / or a criminal fine of at most Rp.1,500,000,000.00 (one billion five hundred million rupiahs)". Moreover, the provisions of Article 25 of the Contempt of Court Bill which was rejected by civil society reads: “1) Any person who publishes or allows to be published on an ongoing trial process, or case that is in the stage of legal remedies, which can affect independence or impartiality, is punished with a maximum imprisonment of 5 (five) years and/or a fine of at most Rp.1,000,000,000.00 (one billion rupiahs). 2) Anyone commenting on a court decision before a decision that has a permanent legal force that can affect the independence of the court is punished with a maximum of 5 (five) years imprisonment and/or a maximum fine of Rp. 1,000,000,000 (one billion rupiah)".

\section{CONCLUSION}

All forms of actions and actions which in principle disrupt safety, psychological and physical calm both inside and outside the trial, can be categorized as Contempt of Court. At present, the Contempt of Court arrangement is implicitly spread in several articles in the Criminal Code. There was much contempt of courts in the process of law enforcement by the judges through the court, but given the absence of clear technical and reporting procedures for the Contempt of Court actions that had not been given strict sanctions, but only issued from the courtroom.

Increasingly expanding various actions that have been categorizing as Contempt of Court which threaten the authority of the court, it is necessary to regulate the Contempt of Court in the form of separate rules. The substance of the Contempt of Court in the Criminal Code Bill has applied to the public outside the law enforcement apparatus. The Criminal Code Bill has not yet regulated what if law enforcers in the judiciary environment such as judges, investigators, and investigators carry out acts that demean the dignity and honour of the judiciary. Provisions that regulate legal protection for law enforcement officers in carrying out their duties are very adequate, but it is undeniable that law enforcers also have the potential to take actions that can undermine the dignity and dignity of the judiciary so that the contempt of court provisions apply also to enforcement officer's law.

\section{REFERENCES}

\section{Book}

Achmad Ali, Menguak Teori Hukum (Legal Theory) dan Teori Peradilan (Judicialprudence), (Jakarta: Kencana, 2012).

Binsar Gultom, Pandangan Seoarang Hakim

Penegak Hukum Di Indonesia, (Medan:

Pustaka Bangsa Press, 2006).

Oemar Seno Adji, Peradilan Bebas Negara

Hukum, (Surabaya: Erlangga, 1986).

\section{Journal}

Aditya W. Mulyadi, 'Urgensi Dan Pengaturan Uu Tentang Contempt Of Court Untuk Menjamin Harkat, Martabat Dan Wibawa Peradilan' (2015) 4(2) Jurnal Magister Hukum Udayana 330.

Anita Afriana and At Al, 'Contempt Of Court: Penegakan Hukum Dan Model Pengaturan Di Indonesia' (2018) 7(3) Jurnal Hukum Dan Peradilan 441.

Budi Suhariyanto, 'Contempt Of Court through the Perspective of Progressive Law' (2016) 9(2) Jurnal Yudisial 151. 
Budi Suhariyanto, 'The Urgency of the Criminalization of Contempt of Court for the Effectiveness of Decision at Judicial State Administrative Court' (2019) 16(1) Jurnal Konstitusi 192.

Hasbullah F. Sjawie, 'Sekelumat Catatan Mengenai Tindak Pidana "Contempt of Court” Di Indonesia' (1994) 4 Jurnal Hukum Dan Pembangunan 324.

Ida K. Jeumpa, 'Contempt Of Court: A Comparison Among Vary Legal Systems' (2014) 62 Kanun Jurnal Ilmu Hukum 147.

Lilik Mulyadi, 'Urgency and Prospects Settings (Ius Constituendum) on Contempt of Court Act to Uphold the Dignity and Justice Authority' (2015) 4(2) Jurnal Hukum dan Peradilan 275.

Nur Kholis, 'Asas Non-Diskriminasi Dalam Contempt of Court' (2018) 26(2), Jurnal Legality 210.

Ruby H. Johny, 'Contempt of Court (Kajian Tentang Ide Dasar Dan Implementasinya Dalam Hukum Pidana)' (2009) 9(2) Jurnal Dinamika Hukum 135.

Sareh Wiyono M, 'Urgensi Pembentukan Undang-Undang Tentang Penghinaan Dalam Persidangan (Contempt of Court), Untuk Menegakkan Martabat dan Wibawa Peradilan' (2015) 4(2) Jurnal Hukum dan Peradilan, 263.

Sutanto Nugroho, R.B. Sulatro and Budhi Wisaksono, 'Pengaturan Tindak Pidana Contempt of Court Berdasarkan Sistem Hukum Pidana Indonesia' (2017) 6(2), Diponegoro Law Journal 1.

Suriani, 'Pengaturan Hukum Pidana Terhadap Contempt Of Court' (2017) 2(3) Jurnal Pionir 1.

Wildan Syafitri, ' Tinjauan Yuridis Penghinaan Terhadap Pengadilan
Dalam Sistem Peradilan Pidana Indonesia' (2016) 3 (2), JOM 1. 